\section{In search of a fertile future}

Norsk Hydro is Norway's largest company and is 51 per cent state owned. With a turnover of NOK 40,000 million and about 31,000 employees, it has come a long way since its origin as a regional producer of fertilizers. Not only has Norsk Hydro joined the ranks of world leaders in fertilizer production by the acquisition of large European companies and investments in new production units, it has also developed major interests in light metals (magnesium and aluminium), petrochemicals, and oil and gas production.

Norsk Hydro's production of oil and gas in 1986 amounted to 4.3 million tonnes of oil equivalent, 80 per cent of which was gas. Rolf Prydz, head of the oil and gas group, says that the company "has been partner as operator or non-operator for some of the most interesting discoveries on the Norwegian continental shelf". The fields at Ekofisk and Frigg account for the greater part of the company's petroleum production. In 1986 research and development in the oil and gas group cost the company NOK 248 million. It is essential, says Prydz, to increase investment in research aimed at profitable oil and gas production even at a price as low as US $\$ 15$ a barrel. Research efforts include improving knowledge of geological conditions in oil fields, enhancing oil recovery and projects for the design of less expensive constructions for the development and operation of oil and gas fields offshore.

The rapid development of the oil sector and its impact on the Norwegian nation has been one of the major events of recent years. The oil and gas fields on the continental shelf of the North Sea constitute some of Norway's most important natural resources. The first production licences were granted in 1965 and output began in 1971. It rose substantially in the second half of the 1970 s when pipelines to Germany and Scotland were built. Norway is now one of Europe's largest exporters of energy products. These represent nearly 30 per cent of the country's total exports. Because of oil, national income has been growing fairly steadily and there is little unemployment despite the fact that the world economic recession has reduced outlets for other Norwegian products.

No industrial position is unassailable, however, and flexibility is needed to respond to the needs of a changing market. The government has designated five priority areas for industrial research in the hope of stimulating rapid growth in other export earnings over the next ten to twenty years.

To meet such demands, Norsk Hydro set up Hydro Innovation in 1985 , to explore potential business areas. The new venture concentrates on biotechnology engine's efficiency.

\section{Fish farming}

(including fish farming), materials technology and offshore technology. Research is being carried out on processing fish waste as fish entrails contain a number of compounds of interest, such as enzymes, water-soluble nutrients and fat compounds. The use of these products in the medical, food manufacturing and chemical industries is being investigated. Light metals, polymers and ceramics are being studied since composite materials with improved qualities of strength, corrosion and heat resistance are being sought, particularly for the automobile industry. There is a drive to reduce harmful emissions, fuel consumption and improve an

\title{
Moving from salmon to flatfish
}

Fish farming has been so successfully developed in Norway that the pioneers of industrial salmon farming, Norsk Hydro have become victims of their own success. Worried that large-scale salmon farming would deprive the traditional fishermen of their living, the government has ruled that licences are required for salmon farming and has granted them mainly to the fishermen on the country's coast. Norsk Hydro has formed subsidiaries in Scotland, Ireland and Iceland.

Most commonly the salmon 'farms' comprise cage structures with a number of separate closed nets linked in a variety of ways to make a complete plant. Such plants demand a relatively small investment and are popular with the people living along the coast of Norway who have set up the salmon farming industry.

Various problems arise with the use of these cages. The temperature and salinity of the water varies in the upper levels depending on season and rainfall. In winter the temperature falls below $4^{\circ} \mathrm{C}$ which is too low for salmon to thrive. Plants located in places with low water

\section{Science parks}

RESEARCH foundations set up around the universities are fast gaining popularity in Norway. For example, one is being established in Oslo and will be run along the lines of the science park at the University of Cambridge in the United Kingdom. It will be financed by a shareholding company involving industry, Oslo University and ten private research institutes

The government is keen to promote links with industry, though it is emphasized that the foundation in Oslo will not be industryled. All parties will have a say in its running. Basic research and industrial research will each represent 40 per cent of the foundation's efforts. The remaining 20 per cent will be 'innovative' research. A comparable development is under way at the University of Bergen.

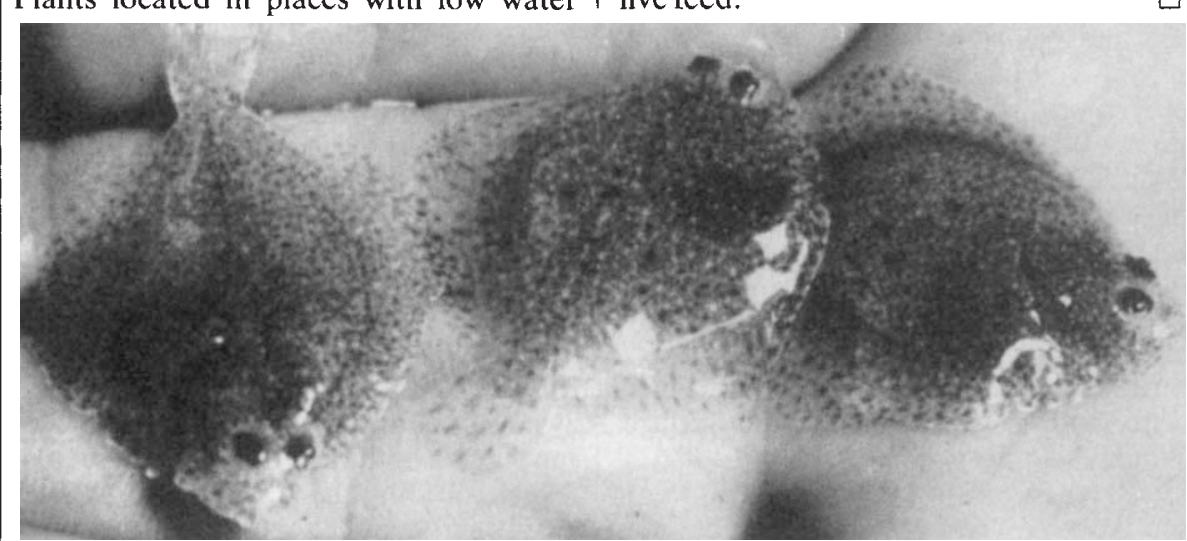

Turbot larvae are small - for turbot and halibut Norsk Hydro are carrying out research into controlled spawning, improved egg quality and how best to provide the larvae with live feed. and excrement accumulating below the cages and impairing the water quality. There is increasing competition in salmon farming and therefore there is a trend towards more industrialization with all stages being monitored and controlled.

In salmon farming, research is concentrated on improving the technology. Particular attention is being paid to improving the binding agents in the feed to increase the nutritional value, the physical environment of farming facilities, and development of new designs of plant. Also, instrumentation is being developed to determine the size and number of fish and to monitor behavioural patterns.

There are also potentially good markets for farmed marine flatfish such as halibut and turbot. SINTEF and companies such as Norsk Hydro are directing a comprehensive research effort in this area. One problem is that halibut and turbot are very sensitive to environmental conditions. In addition marine flatfish larvae are much smaller than salmon and require live feed. 